\title{
Diversity, floristic composition and structure of the woody vegetation of the Cerrado in the Cerrado-Amazon transition zone in Mato Grosso, Brazil
}

Leonardo Maracahipes-Santos, Eddie Lenza, Josias Oliveira dos Santos, Beatriz Schwantes Marimon, Pedro V. Eisenlohr, Ben Hur Marimon-Junior, Ted R. Feldpausch

L. Maracahipes-Santos (e-mail), E. Lenza, J. O. Santos, B.S. Marimon, B. H. Marimon-Junior e-mail: maracahipes@hotmail.com

Programa de Pós-Graduação em Ecologia e Conservação, Universidade do Estado de Mato Grosso, Caixa Postal 08, 78690-000, Nova Xavantina-MT, Brasil. telefone/fax: (66) 3438-2675

P. V. Eisenlohr

Universidade do Estado de Mato Grosso, Caixa Postal 324, 78580-000, Alta Floresta-MT, Brasil.

T. R. Feldpausch

Geography, College of Life and Environmental Sciences, University of Exeter, Exeter EX4 4RJ, UK.

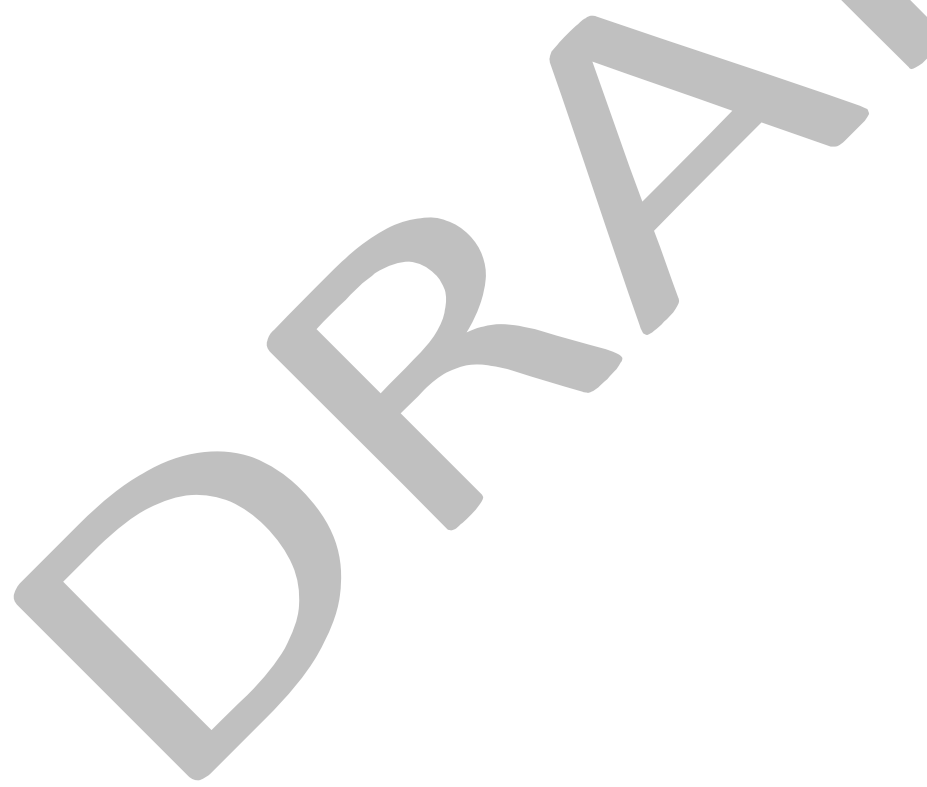


Abstract: We compared the diversity and species composition, and the structure of the vegetation of three distinct Cerrado phytophysiognomies (Cerradão, Dense Cerrado, and Typical Cerrado) in the Cerrado-Amazon transition, Mato Grosso (Brazil). Species richness (observed and estimated) in the Cerradão and Dense Cerrado was higher than that recorded in the Typical Cerrado. Species diversity, based on a Rényi profile, was highest in the Dense Cerrado, in comparison with the other phytophysiognomies. We recorded a higher number of exclusive species in the Cerradão, and a greater similarity (Morisita and Sørensen indices) between this vegetation type and the Dense Cerrado. While individuals were tallest in the Cerradão and Dense Cerrado and lowest in the Typical Cerrado, there was no difference among phytophysiognomies in mean diameter. A gradient in decreasing species richness and diversity (hypothesis 1) and vegetation vertical structure (hypothesis 3) was expected for the Cerradão-Dense Cerrado-Typical Cerrado; however, neither hypothesis was supported by the results. The Cerradão and Dense Cerrado were most similar in species composition not confirming hypothesis 2 , which predicted that the two savanna vegetation types (Dense Cerrado and Typical Cerrado) were more similar to one another than either is to the woodland (Cerradão). Overall, the similarities among the three study communities depended on the type of parameter analyzed. While the species richness and the vertical and structure of the vegetation of the Cerradão and Dense Cerrado are closely similar, the Cerradão and Typical Cerrado are more similar in their species diversity. With regard to the floristic composition, Dense Cerrado occupies an intermediate position between Cerradão and Typical Cerrado.

Key words: Conservation, floristic similarity, indicator species, mean height.

\section{Introduction}

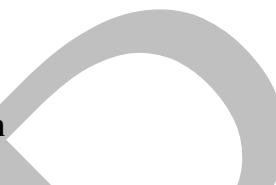

The South American Cerrado biome is the most diverse and species-rich of all the world's savannas (Mendonça et al. 2008), due to the marked heterogeneity of habitats and soils (Ribeiro and Walter 2008; Reatto et al. 2008), the occurrence of bushfires (Hoffmann and Franco 2003; Hoffmann et al. 2012), and landscape relief (Oliveira-Filho et al. 1989; Marimon et al. 1998). In addition to these complex environmental factors, the contact zones among Cerrado and four other Brazilian biomes (Amazon, Atlantic Rain forest, Pantanal and Caatinga) (Ribeiro and Walter 2008) can contribute to the tree species diversity.

In the Cerrado-Amazon contact zones of ecological tension, the interchange of species contributes to increased richness and influences the species composition (Castro and Martins 1999; Méio et al. 2003). 
The most extensive zone of contact is located in southern and southeastern Amazon (Marimon et al. 2006; Miranda et al. 2006; Ribeiro and Walter 2008). Here, the vegetation of both biomes intermingle, forming a complex matrix (Askew et al. 1970; Marimon et al. 2006) with a singular distribution of tree species along the hyperdynamic vegetation in the transitional Cerrado-Amazon landscapes (Marimon et al. 2014). As this region also coincides with the "Arc of Deforestation" in the Brazilian agricultural frontier, it is of considerable importance for the conservation of the country's biodiversity (Nogueira et al. 2008; Domingues and Bermann 2012).

Scientific studies of the Cerrado-Amazon transition zone in eastern Mato Grosso began with the classic, descriptive works of the Xavantina-Cachimbo Expedition (Askew et al.1970; Eiten 1972; Ratter et al. 1973). The local vegetation is composed predominantly of semi-deciduous forests, known as transitional forest (Marimon et al. 2006; Balch et al. 2008; Hoffmann et al. 2012), the composition of which is influenced primarily by the Amazon rainforest, and only to a lesser extent by the Cerrado (Méio et al. 2003). A number of other vegetation types and subtypes (sensu Ribeiro and Walter 2008) can be found in the region, with a predominance of Cerrado species (Askew et al. 1970; Marimon-Junior and Haridasan 2005; Maracahipes et al. 2011). More recent studies suggest that the savanna formations of the transition zone are characterized by higher diversity than similar areas on the central Brazilian plateau (Felfili et al. 2002; Kunz et al. 2009; Gomes et al. 2011; Lenza et al. 2011; Maracahipes et al. 2011).

The Cerradão is the only woodland habitat sensu lato found in the Cerrado (sensu Ribeiro and Walter 2008) and is characterized both by generalist tree species, as well as those more typical of either the savanna or forest formations of the Cerrado (Oliveira-Filho and Ratter 1995; Marimon-Junior and Haridasan 2005; Ribeiro and Walter 2008; Solórzano et al. 2012). The savanna formations of the Cerrado include Dense Cerrado and Typical Cerrado, which can be differentiated in terms of the density of the vegetation, and canopy cover and height, but tend to be very similar in terms of species composition (Ribeiro and Walter 2008). Tree cover in the Dense Cerrado is between $50 \%$ and $70 \%$, with a canopy height of 5-8 $\mathrm{m}$ (Ribeiro and Walter 2008). The Typical Cerrado is the most widespread vegetation subtype in the Cerrado sensu stricto (Ribeiro and Walter 2008), and is characterized by tree cover of 20$50 \%$, with a canopy of 3-6 $\mathrm{m}$ in height (Ribeiro and Walter 2008).

Local studies comparing Cerrado vegetation types and subtypes have provided important insights into the formation of distinct habitats, and the conservation and management of the biome's biodiversity (Oliveira-Filho et al. 1989; Marimon et al. 1998; Marimon-Junior and Haridasan 2005; Gomes et al. 
2011). In their comparison of Cerradão and Typical Cerrado, Marimon-Junior and Haridasan (2005) found marked differences in species composition, and vegetation structure. In Typical and Rocky Cerrado, Gomes et al. (2011) found marked differences in the most important species in terms of community structure. In their study of Cerradão, Dense Cerrado and Typical Cerrado in São Paulo (Brazil), Pinheiro and Durigan (2012) recorded structural differences in basal area classes, canopy cover, and the diameter and height of the largest trees. These findings emphasize the importance of understanding both the species composition and structure of the vegetation for the interpretation of the features of the different phytophysiognomies.

In the present study, our main objective was to characterize and compare the diversity, species composition, and structure of the woody vegetation of three Cerrado sites, representing the Cerradão (forest facies), Dense Cerrado, and Typical Cerrado, in the Cerrado-Amazon transition zone in Mato Grosso (Brazil). We tested three hypotheses related to the distributions of tree species in the transitional Cerrado-Amazon transitional landscapes: (1) because of the co-existence of savanna and forest species in the Cerradão, there is a decreasing gradient in tree species richness and diversity from this vegetation to Dense and Typical Cerrado; (2) the species composition and horizontal structure of the vegetation is more similar between Typical and Dense Cerrado than between either of these and the Cerradão woodland; (3) there is a decreasing gradient in height, diameter, density, and total basal area of the trees from the Cerradão and the Typical Cerrado.

\section{Material and methods}

Study area - The study focused on three Cerrado sites with distinct vegetation types, which represent a gradient in density, height, and the shrubby component of the canopy in the Cerrado-Amazon transition areas. One site was representative of the Cerradão (CO: $12^{\circ} 49^{\prime} 26.8^{\prime \prime} \mathrm{S}, 051^{\circ} 46^{\prime} 06.0^{\prime \prime} \mathrm{W}$ ), one of the Dense Cerrado (DC - 12 ${ }^{\circ} 49^{\prime} 07.6^{\prime \prime} \mathrm{S}, 051^{\circ} 46^{\prime} 12.3^{\prime \prime} \mathrm{W}$ ) and one of the Typical Cerrado (TC: $12^{\circ} 50^{\prime} 02.5^{\prime \prime}$ S, 05145'55.9” W) sensu Ribeiro and Walter (2008), located in the Cerrado-Amazon transition zone in the municipality of Ribeirão Cascalheira, in the State of Mato Grosso, Brazil (Figure 1). The local climate is characterized by a well-defined rainy season, from May to September, with rainfall peaking from November to Febuary, and dry conditions, including soil water deficits during the rest of the year (Silva et al. 2008). 
Data collection - We established a $100 \mathrm{~m} \times 100 \mathrm{~m}$ plot at each of the three sites divided into 25 subplots of $20 \mathrm{~m} \times 20 \mathrm{~m}$. All live woody plants with diameter at $30 \mathrm{~cm}$ above the ground $\left(\mathrm{D}_{30}\right)$ of at least $5 \mathrm{~cm}$ were identified and marked with aluminum tags. We measured the total height of each individual with a laser rangefinder and stem diameter with a measuring tape. For individuals with multiple stems, all the stems were measured for the subsequent calculation of the quadratic diameter (Moro and Martins 2011). We conducted the data collection in three field campaigns with five days each, the first one in July 2013 (Dense Cerrado) and the other two in September 2013 (Cerradão and Typical Cerrado).

Whenever possible, we identified the species in the field, but when necessary, we collected specimens for comparison with those available in the Herbarium NX, of the collection James Alexander Ratter (State University of Mato Grosso at Nova Xavantina) and in appropriate references. The system suggested by the Angiosperm Phylogeny Group (APG III 2009) was used to classify the families, with the taxonomy revised and updated based on the List of Brazilian Flora (2014).

Data analysis - We compared the species richness recorded at the three sites using the rarefaction technique with the standardization of sampling effort by the number of individuals recorded (Gotelli and Colwell 2001; Magurran 2011), using the $S_{o b s}$ Mao Tau estimator with 1000 randomizations. The species richness at the three sites was also estimated using Jackknife 1, which was the estimator that correlated most closely with observed richness (Walther and Moore 2005). We used diversity profiles based on the Rényi exponential series (Tóthmérész 1995) to compare diversity at the three study sites, in which alpha corresponds to Shannon's index, and alpha 2 to Simpson's index (Melo 2008).

We evaluated the similarity in species composition among the three sites using the quantitative Morisita-Horn $\left(\mathrm{Cm}_{\mathrm{H}}\right)$ coefficient (Magurran 2011) and the binary (qualitative) coefficient of Sørensen (Ss) (Brower and Zar 1984). A two-way indicator species analysis (TWINSPAN: Hill et al. 1975) was used to classify the vegetation, with eigenvalues above 0.3 being considered to represent strong ecological divisions (Hill 1979; Felfili et al. 2007, 2011).

We used an Indicator Species Analysis (ISA) to identify the species considered to be indicators of a given vegetation type, together with a Monte Carlo test to verify the significance of the classification (Dufrêne and Legendre 1997; McCune and Mefford 1999). We described the horizontal structure of the vegetation using the absolute density of individuals and the Importance Value Index (IVI), as proposed by Curtis and McIntosh (1950) and Mueller-Dombois and Ellenberg (1974). 
We used an Analysis of Variance (ANOVA) to compare trunk diameter, tree height, and mean density per subplot among sites. When the assumptions of normality and homogeneity of variance were not satisfied, we used an ANOVA with Welch's $F$ test for heterogeneous variables (Zar 2010). All analyses were complemented with Tukey’s post hoc test.

Structural parameters were analyzed in FITOPAC 2.1.2 (Shepherd 2009), diversity and similarity were evaluated in PC-ORD version 6.07 (McCune and Mefford 2011), TWINSPAN and ISA were run in PAST (PAleontological STatistics) version 2.15 (Hammer et al. 2001), while R 3.0.2 (R Core Team 2013) was used for all other analyses. In all cases, the normality of the data was assessed using the ShapiroWilk test and the homogeneity of variance was confirmed by Levene's test (Zar 2010) and a 5\% significance level was considered.

\section{Results}

We sampled a total of 5946 individuals at the three sites, belonging to 115 species, 80 genera, and 40 families. We recorded 2186 individuals, 91 species, 67 genera, and 35 families in the Cerradão (CO) and 2070 individuals of 91 species, 68 genera, and 37 families in the Dense Cerrado (DC). In the Typical Cerrado (TC) we sampled 1690 individuals belonging to 76 species, 56 genera, and 32 families (Table 1).

The species richness estimated by rarefaction (Figure 2) was lowest in the Typical Cerrado (76 species), but remarkably similar between the Cerradão (86.7 \pm 8.9 species) and the Dense Cerrado ( $86.8 \pm 8.7$ species). Observed species richness (76) in the Typical Cerrado was the most similar (89\%) to the estimated number $(85.0 \pm 12.9)$. In the case of the Cerradão, observed richness was $91 \mathrm{species,} 84 \%$ of the estimated value $(108.0 \pm 11.4$ species $)$, while in the Dense Cerrado, observed richness was also 91

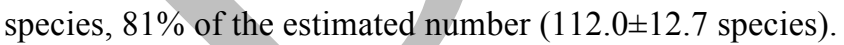

The Dense Cerrado had the highest diversity in comparison with the Cerradão and Typical Cerrado (Figure 3). The other two vegetation types were closely similar to one another.

Of the total of 115 species recorded in the present study, $54(47 \%)$ were common to all three sites, and $26(23 \%)$ were exclusive to two of the sites. The largest number of exclusive species was recorded in the CO plot, followed by TC and DC (Figure 4; Table 1). The highest similarity values were found between the Cerradão and Dense Cerrado, and the lowest, between Cerradão and Typical Cerrado, considering both the quantitative Morisita index, and the qualitative Sørensen index (Figure 4). The TWINSPAN classification initially grouped all the 25 Cerradão subplots with four of the Dense Cerrado 
plots (eigenvalue $=0.33$, while all the remaining subplots were grouped together (Figure 5). A total of 24 indicator species were recorded in the Cerradão, 16 in the Dense Cerrado, and 20 in the Typical Cerrado. Despite these large numbers of indicator species at each site (Monte Carlo, $\mathrm{p}<0.001$ ), the large numbers of species common to two or more sites contributed to high indices of similarity (Table 1; Figure 4).

The most structurally important species (highest IVI values: see Table 1) in the Cerradão were Myrcia splendens (Sw.) DC., Pterodon pubescens (Benth.) Benth., Xylopia sericea A.St.-Hil., Roupala montana Aubl., Syagrus comosa (Mart.) Mart., Emmotum nitens (Benth.) Miers, Mezilaurus crassiramea (Meisn.) Taub. ex Mez, Pouteria ramiflora (Mart.) Radlk., Qualea grandiflora Mart. and Tachigali vulgaris L.G.Silva \& H.C.Lima (53.6\% of the total). In the Dense Cerrado, the most important species were E. nitens, Mouriri elliptica Mart., S. comosa, M. splendens, R. montana, P. ramiflora, X. sericea, Myrcia multiflora (Lam.) DC., Bowdichia virgilioides Kunth and M. crassiramea (50.9\% of the total), while in the Typical Cerrado, they were S. comosa, Davilla elliptica A.St.-Hil., Qualea parviflora Mart., M. crassiramea, Byrsonima verbascifolia A.St.-Hil., Myrcia rimosa Cambess., Eugenia dysenterica DC., Byrsonima coccolobifolia Kunth and Curatella americana L. (49.4\% of the total). Among the ten species with the highest IVI in each phytophysiognomy, seven were common among the Cerradão and the Dense Cerrado, and only two were common between the three phytophysiognomies (Table 1). These results suggest a higher similarity, with regard to horizontal structure, between the Cerradão and Dense Cerrado and lesser resemblance between these two phytophysiognomies and the Typical Cerrado.

Mean tree height was significantly higher (Welch's $\mathrm{F}_{(2,3935)}=626.70, \mathrm{p}<0.01$ ) in the Cerradão $(5.5 \pm 2.4 \mathrm{~m}, \mathrm{SD})$ in comparison with the Dense $(4.5 \pm 2.3 \mathrm{~m})$ and Typical Cerrado $(3.0 \pm 1.98 \mathrm{~m})$. However, mean diameter varied little $\left(\mathrm{F}_{(2,3884)}=0.66, \mathrm{p}=0.52\right)$ among the Cerradão $(9.5 \pm 4.7 \mathrm{~cm})$, Dense Cerrado $(9.6 \pm 5.0 \mathrm{~cm})$ or Typical Cerrado $(9.5 \pm 4.5 \mathrm{~cm})$. Despite these similarities in the diameter of individuals, the mean densities recorded in the subplots at the three sites varied significantly $\left(\mathrm{F}_{(2,72)}=28.09 ; \mathrm{p}<0.01\right)$, with the lowest density being recorded in the Typical Cerrado $\left(67.6 \pm 9.4\right.$ inds.ha $\left.^{-1}\right)$, with much higher values being recorded in the Cerradão $\left(87 \pm 8.85\right.$ inds.ha $\left.^{-1}\right)$ and Dense Cerrado $\left(83 \pm 11.0\right.$ inds.ha $\left.{ }^{-1}\right)$. The lower density recorded in the Typical Cerrado also accounts for the reduced basal area recorded in this vegetation type $\left(14.5 \mathrm{~m}^{2} \cdot \mathrm{ha}^{-1}\right)$ in comparison with the Cerradão $\left(19.3 \mathrm{~m}^{2} \cdot \mathrm{ha}^{-1}\right)$ and Dense Cerrado (19.1 $\left.\mathrm{m}^{2} \cdot \mathrm{ha}^{-1}\right)$.

\section{Discussion}


The high species richness recorded in the present study (91 in Cerradão and Dense Cerrado; 76 species in Typical Cerrado) has also been found in other cerrado communities in eastern Mato Grosso. For example, in Cerradão, Kunz et al. (2009) registered 95 species, Franczak et al. (2011) found between 84 and 87 species, and Solórzano et al. (2012) sampled 124 species. In Cerrado sensu stricto, Nogueira et al. (2001) observed 88 species, Felfili et al. (2002) found 80 species, and Marimon-Junior and Haridasan (2005) recorded 77 species, and Gomes et al. (2011), 79 species. Lenza et al. (2011) also found evidence of marked differences in the species composition of these transitional cerrados in comparison with those located towards the center of the biome. Felfili et al. (2002) concluded that the unique features of these Cerrados were related to the influence of Amazonian ecosystems. Together, these findings emphasize the floristic importance of the Cerrados of this region for the conservation of its woody flora.

The relatively low observed and estimated species richness recorded for the Typical Cerrado in comparison with the other two vegetation types appears to be typical of the Cerrado in general, given that Pinheiro and Durigan (2012) obtained similar results in a study of the Cerrado in São Paulo. In addition, data on the Cerradão from the same region as the present study (Kunz et al. 2009; Franczak et al. 2011; Solórzano et al. 2012) indicate similarly high levels of species richness in comparison with areas of Typical Cerrado (Felfili et al. 2002; Marimon-Junior and Haridasan 2005; Gomes et al. 2011). This indicates the existence of a gradient of species richness between the more open and woodland habitats associated with density and basal area.

The relatively higher species diversity recorded in the Dense Cerrado in comparison with the other two vegetation types may reflect the more equitable distribution of individuals among species in these types and the lower species richness for Typical Cerrado. The higher diversity of the Dense Cerrado compared to the others may also be related to the intermediate nature of this vegetation type, between the Cerradão and Typical Cerrado. This may be because neither the species characteristic of forest formations (which are abundant in the Cerradão) nor those that predominate in more open savannas (abundant in the Typical Cerrado) were dominant in the Dense Cerrado. Previous comparative studies of Cerrado habitats, such as those of Pinheiro and Durigan (2012), Marimon-Junior and Haridasan (2005), and Costa and Araújo (2001) have applied only a single diversity index, rather than a variety of indices that weight common and rare species differently. Based on this condition, we would recommend the application of diversity profiles for the better understanding of structural differences in comparative studies, as also suggested by Melo (2008). 
These results show a decrease in plant richness from Cerradão and Dense to Typical Cerrado, but not for diversity. The fact that tree species diversity in Dense Cerrado was higher than the others, demonstrates, in sum, that Dense Cerrado is an intermediate situation of species composition and possibly a temporal stage between Cerradão and Typical Cerrado. This state can reveal evidence of shifts between forest and savanna (forest advances into Cerrado) over the last millennium as previously recorded by Ab'Saber (1977, 2002), and recently investigated by the TROBIT Project (Saez, Lloyd, Marimon-Junior et al., unpublished data) in the same area of this study.

The high similarity of the species found at the three sites, especially in qualitative terms, and the large proportion of species in common (approximately 50\%) could be a consequence of the geographic proximity of the sites, which are separated by distances of only $0.5-3 \mathrm{~km}$, and reinforces the lack of any specific identity for these communities. A number of authors have found that the woody vegetation of adjacent cerrado to forest communities may be highly similar, irrespective of the similarities in substrate conditions (Silva et al. 2006; Gomes et al. 2011; Mews et al. 2014). In the present study, this is probably due to the physicochemical similarities of the soil among sites and the interchange of species - especially the more generalist forms - among communities.

However, a small number of habitat specialist tree species may contribute to marked divergences in the species composition of adjacent communities. This may account for the reduced similarity observed between the Cerradão woodland and the Typical Cerrado savanna samples, in particular, and the larger number of exclusive Cerradão species. The Dense Cerrado was more similar to both Cerradão and Typical Cerrado, however, and subplots that grouped with both vegetation types in the TWINSPAN analysis, reinforcing the transitional and intermediate characteristics of this vegetation type, and the existence of a floristic gradient. This may also account for the reduced similarity between the Cerradão and the Typical Cerrado, observed in both the present and previous studies (Marimon-Junior and Haridasan 2005; Pinheiro and Durigan 2012).

While all three phytophysiognomies presented an oligarchic pattern, that is, the predominance of a only a few species in the structure of the community, only two species - Syagrus comosa (Mart.) Mart. and Mezilaurus crassiramea (Meisn.) Taub. ex Mez - were among the ten most predominant at all three sites. Structural oligarchy is common in the plant communities of the Cerrado sensu lato (Ratter et al. 2003; Bridgewater et al. 2004; Felfili et al. 2008) and indicates that a small group of species is adapted to the environment and the competition with one another in such a way as to guarantee their dominance of 
the communities (Solórzano et al. 2012). In the present study, however, the reduced coincidence among more dense and forested phytophysiognomies (Cerradão and Dense Cerrado) and predominantly savannic community (Typical Cerrado) in the structurally dominant species and the high number of indicator species identified for each community reflect the structural differences among vegetation types. The distinct conditions found in each type, related to differences in tree density and height, appear to favor the predominance of different species in the three communities. In particular, Myrcia splendens (Sw.) DC., Xylopia sericea A.St.-Hil., Roupala montana Aubl., Emmotum nitens (Benth.) Miers and Pouteria ramiflora (Mart.) Radlk. are the species most well adapted to the forested habitats (Cerradão and Dense Cerrado), while Davilla elliptica A.St.-Hil., Qualea parviflora Mart., Byrsonima verbascifolia A.St.-Hil., Bowdichia virgilioides Kunth, Byrsonima coccolobifolia Kunth, Eugenia dysenterica DC. and Curatella americana L., seem most adapted to the open savanna environments (Typical Cerrado).

Surprisingly, mean tree diameter did not vary significantly among sites, although the individuals in the Cerradão and Dense Cerrado were taller than those found in the Typical Cerrado, indicating that the plants in the denser vegetation types invest more in upward growth than the enlargement of their stems. In addition, despite the similarities in stem diameter, the highest basal area recorded in the Cerradão and Dense Cerrado was determined by the highest tree densities recorded in these vegetation types.

The first hypothesis - that there is a systematic Cerradão-Dense Cerrado-Typical Cerrado gradient of (decreasing) species richness and diversity - was not supported by the findings of this study, given that these parameters were very similar in the Cerradão and Dense Cerrado, and much higher than the values recorded for the Typical Cerrado. In addition, the highest species diversity was recorded in the Dense Cerrado, rather than the Cerradão. The second hypothesis was also denied, given that similarity index (Morisita-Horn and Sørensen) and common species between Dense and Typical Cerrado was lower than that between Dense Cerrado and Cerradão. Rather than that, these results indicate that Dense Cerrado occupies an intermediate position between Cerradão and Typical Cerrado in terms of floristic composition. This is confirmed by TWINSPAN analysis which groups the Dense Cerrado plots with both Cerradão and Typical Cerrado plots. The third hypothesis, which predicted a gradient in structural parameters, the results once again led to rejection of the hypothesis, given the marked similarities of the Cerradão and Dense Cerrado, although tree height did vary systematically, decreasing from the Cerradão to the Dense Cerrado and then to the Typical Cerrado. 
Overall, the similarities or differences among the three communities surveyed in the present study changed depending on the variables analyzed. While the Cerradão and Dense Cerrado were similar to one another in terms of species richness and the vertical and horizontal structure of the vegetation, the Cerradão and Typical Cerrado were similar in terms of species diversity. Finally, we observed a not predicted gradient in species composition, in wich Cerradão and Typical Cerrado occupy the extremes and the Dense Cerrado a transitional position. From a conservation perspective, our results emphasize the importance of the protection of the three types of vegetation, not only for the preservation of beta diversity, but also the conservation of species that prefer either forested habitats or more open, savanna environments along the Cerrado-Amazon transition zone.

\section{Acknowledgments}

We are grateful to the UNEMAT Graduate Program in Ecology and Conservation and the Brazilian Higher Education Training Program (CAPES) for financial support and the concession of a graduate scholarship, the projects "Tropical Biomes in Transition - TROBIT", CAPES/Science without Borders Program (Project 177/2012), PELD/CNPq (Long-Term Ecological Studies) and PROCAD UnB/UNEMAT for financial and logistic support during the fieldworks and data analysis. We would also like to thank Bianca de Oliveira, Simone Matias Almeida Reis, Firmino Cardoso Pereira, Fábio Barbosa Passos and Leandro Maracahipes, from the NX Plant Ecology Laboratory for their help with the collection of field data. We thank also the owners of the farm Santa Marta, where this study was conducted.

\section{References}

Ab’Saber AN (1977) Espaços ocupados pela expansão dos climas secos na América do Sul, por ocasião dos períodos glaciais quaternários. Paleoclimas 3:1-19

Ab’Saber AN (2002) Bases para o estudo dos ecossistemas da Amazônia brasileira. Estud Av 16:7-30 APG III (2009) An update of the Angiosperm Phylogeny Group classification for the orders and families of flowering plants: APG III. Bot J Linn Soc 161:105-121

Askew GP, Moffatt DJ, Montgomery RF, Searl PL (1970) Interrelationships of soils and vegetation in the savanna-forest boundary zone of north eastern Mato Grosso. Geogr J 136:370-376 
Balch JK, Nepstad DC, Brando PM, Curran LM, Portela O, Carvalho-Júnior O, Lefebvre P (2008) Negative fire feedback in a transitional forest of southeastern Amazonia. Glob Change Biol 14:22762287

Bridgewater S, Ratter JA, Ribeiro JF (2004) Biogeographic patterns, $\beta$-diversity and dominance in the Cerrado biome of Brazil. Biodivers Conserv 13:2295-2318

Brower JE, Zar JH (1984) Field and laboratory methods for general ecology. Dubuque. WM. C. Brown Publishers

Castro AAJF, Martins FR (1999) Cerrados do Brasil e do Nordeste: caracterização, área de ocupação e considerações sobre a sua fitodiversidade. Pesq Foco 7:147-178

Costa AA, Araújo GM (2001) Comparação da vegetação arbórea de cerradão e de cerrado na reserva do Panga, Uberlândia, Minas Gerais. Acta Bot Bras 15:63-72

Curtis JT, McIntosh RP (1950) The interrelations of certain analytic and synthetic phytosociological characters. Ecology 31:434-455

Domingues MS, Bermann C (2012) O arco de desflorestamento na Amazônia: da pecuária à soja. Ambiente Soc 15:1-22

Dufrêne M, Legendre A (1997) Ecological Society of America species assemblages and indicator species: the need for a flexible asymmetrical approach. Ecol Monogr 67:345-366

Eiten, G., 1972. The cerrado vegetation of Brazil. Bot Rev 38:201-341

Felfili JM, Nogueira PE, Silva-Júnior MC, Marimon BS, Delitti WBC (2002) Composição florística e fitossociológica do cerrado sentido restrito no município de Água Boa-MT. Acta Bot Bras 16:103112

Felfili JM, Carvalho FA, Libano AM, Venturoli F, Pereira BAS, Machado ELM (2007) Análise multivariada em estudos de vegetação. Universidade de Brasília, Faculdade de Tecnologia, Departamento de Engenharia Florestal, Brasília, pp 60

Felfili JM, Carvalho FA, Libano AM, Venturoli F, Pereira BAS, Machado ELM (2011) Análise multivariada: princípios e métodos em estudos de vegetação. In: Felfili JM, Eisenlohr PV, Melo MMRF, Andrade LA, Meira Neto JAA (eds.) Fitossociologia no Brasil: métodos e estudo de casos. Universidade Federal de Viçosa, pp 130-131

Felfili JM, Felifili MC, Nogueira PE, Silva JF, Fariñas MR, Nunes M, Silva-Júnior MC, Rezende AV, Fagg CW (2008) Padrões fitogeográficos e sua relação com sistemas de terra no bioma Cerrado. In: 
Sano SM, Almeida SP, Ribeiro JF (eds.) Cerrado: Ecologia e Flora. Embrapa Informação Tecnológica, Brasília, pp 215-228

Franco A (2005) Biodiversidade de forma e função: implicações ecofisiológicas das estratégias de utilização de água e luz em plantas lenhosas do Cerrado. In: Scariot A, Souza-Silva JC, Felfili JM (orgs.) Cerrado: ecologia, biodiversidade e conservação. Ministério do Meio Ambiente, Brasília, pp $179-196$

Franczak DD, Marimon BS, Marimon-Junior BH, Mews HA, Maracahipes L, Oliveira E A (2011) Changes in the structure of a savanna forest over a six-year period in the Amazon-Cerrado transition, Mato Grosso state, Brazil. Rodriguésia 62:425-436

Gomes L, Lenza E, Maracahipes L, Marimon BS, Oliveira EA (2011) Comparações florísticas e estruturais entre duas comunidades lenhosas de cerrado típico e cerrado rupestre, Mato Grosso, Brasil. Acta Bot Bras 25:865-875

Gotelli NJ, Colwell RK (2001) Quantifying biodiversity: procedures and pitfalls in the measurement and comparison of species richness. Ecol Lett 4:379-391

Hammer Ø, Harper DAT, Ryan PD (2001) Past: Paleontological Statistics Software Package for Education and Data Analysis. Palaeontol Electron 4:9

Hill M, Bunce RGH, Shaw MW (1975) Indicator species analysis, a divisive poythetic method of classification and its application to a survey of native pinewoods in Scotland. J Ecol 63:597-613

Hill MO (1979) TWINSPAN: a fortran program for arranging multivariate data in an ordered two-way table by classification of the individuals and attributes. Cornell University, Ithaca, New York

Hoffmann WA, Franco AC (2003) Comparative growth analysis of tropical forest and savanna woody plants using phylogenetically independent contrasts. J Ecol 91:475-484

Hoffmann WA, Geiger EL, Gotsch SG, Rossatto DR, Silva LCR, Lau OL, Haridasan M, Franco AC (2012) Ecological thresholds at the savanna-forest boundary: how plant traits, resources and fire govern the distribution of tropical biomes. Ecol Lett 15:759-768

Kunz SH, Ivanauskas NM, Martins SV (2009) Estrutura fitossociológica de uma área de cerradão em Canarana, Estado do Mato Grosso, Brasil. Acta Sci Biol Sci 32:255-261

Lenza E, Pinto JRR, Pinto AS, Maracahipes L, Bruziguessi EP (2011) Comparação da vegetação arbustivo-arbórea de uma área de cerrado rupestre na Chapada dos Veadeiros, Goiás, e áreas de cerrado sentido restrito do Bioma Cerrado. Rev bras Bot 34:247-259 
Lista de Espécies da Flora do Brasil. Jardim Botânico do Rio de Janeiro. Disponível em: $<$ http://floradobrasil.jbrj.gov.br/>. Accessed 10 January 2014

Magurran AE (2011) Medindo a diversidade biológica. UFPR ed., Universidade Federal do Paraná, Curitiba, pp 261

Maracahipes L, Lenza E, Marimon BS, Oliveira EA, Pinto JRR, Marimon-Junior BH (2011) Estrutura e composição florística da vegetação lenhosa em cerrado rupestre na transição Cerrado Floresta Amazônica, Mato Grosso, Brasil. Biota Neotrop 11:133-141

Marimon BS, Marimon-Junior BH, Feldpausch T, Oliveira-Santos C, Mews HA, Lopez-Gonzales G, Lloyd J, Franczak DD, Oliveira EA, Maracahipes L, Miguel A, Lenza E, Phillips O (2014) Disequilibrium and hyperdynamic tree turnover at the forest-cerrado transition zone in southern Amazonia. Plant Ecol Divers 7:281-292

Marimon BS, Lima ES, Duarte TG, Chieregatto LC, Ratter JA (2006) Observations on the Vegetation of Northeastern Mato Grosso, Brazil. IV.* An Analysis of the Cerrado-Amazonian Forest Ecotone. Edinb J Bot 63:323-341

Marimon BS, Varella RF, Marimon-Junior BH (1998) Fitossociologia de uma área de cerrado de encosta em Nova Xavantina, Mato Grosso. Bol Herb Ezechias Paulo Heringer 3:82-101

Marimon-Junior BH, Haridasan M (2005) Comparação da vegetação arbórea e características edáficas de um cerradão e um cerrado sensu stricto em áreas adjacentes sobre solo distrófico no leste de Mato Grosso, Brasil. Acta Bot Bras 19:913-926

McCune B, Mefford MJ (1999) Multivariate Analysis of Ecological Data. Gleneden Beach, MjM Software

McCune B, Mefford MJ (2011) PC-ORD. Multivariate Analysis of Ecological Data. Version 6.07, Gleneden Beach, MjM Software

Méio BB, Freitas CV, Jatobá L, Silva MEF, Ribeiro JF, Henriques RPB (2003) Influência da flora das florestas Amazônica e Atlântica na vegetação do cerrado sensu stricto. Rev bras Bot 26:437-444 Mendonça RC, Felfili JM, Walter BT, Silva-Júnior MC, Rezende AV, Filgueiras TS, Nogueira PE, Fagg CW (2008) Flora Vascular do bioma Cerrado: checklist com 12.356 espécies. In: Sano SM, Almeida SP, Ribeiro JF (eds.). Cerrado: ecologia e flora. Embrapa Cerrados, Planaltina, pp 421-1279 
Mews H, Pinto JRR, Eisenlohr PV, Lenza E (2014) Does size matter? Conservation implications of differing woody population sizes with equivalent occurrence and diversity of species for threatened savanna habitats. Biodivers Conserv 23:1119-1131

Miranda IS, Almeida SS, Dantas PJ (2006) Florística e estrutura de comunidades arbóreas em cerrados de Rondônia, Brasil. Acta Amaz 36:419-430

Moro MF, Martins FR (2011) Métodos de levantamento do componente arbóreo-arbustivo. In: Felfili JM, Eisenlohr PV, Melo MMRF, Andrade LA, Meira Neto JAA (orgs.). Fitossociologia no Brasil: Métodos e estudos de casos. Universidade Federal de Viçosa, pp 174-212

Mueller-Dombois D, Ellenberg H (1974) Aims and methods of vegetation ecology. John Wiley \& Sons, New York, pp 547

Nogueira EM, Nelson BW, Fearnside PM, França MB, Oliveira CA (2008) Tree height in Brazil's 'arc of deforestation': Shorter trees in south and southwest Amazonia imply lower biomass. Forest Ecol Manag 255:2963-2972

Nogueira PE, Felfili JM, Silva-Júnior MC (2001) Composição Florística e fitossociologia do cerrado sentido restrito no município de Canarana - MT. Bol Herb Ezechias Paulo Heringer 8:28-43

Oliveira-Filho AT, Ratter JA (1995) A study of the origin of central Brazilian forests by the analysis of plant species distribution patterns. Edinb J Bot 52:141-194

Oliveira-Filho AT, Shepherd GJ, Martins FR, Stubblebine WH (1989) Environmental factors affecting physiognomic and floristic variation in an area of cerrado in Central Brazil. J Trop Ecol 5:413-431

Pinheiro ES, Durigan G (2012) Diferenças florísticas e estruturais entre fitofisionomias do Cerrado em Assis, SP, Brasil. Rev Arvore 36:181-193

R Core Team (2013) R: A language and environment for statistical computing. R Foundation for Statistical Computing, Vienna, Austria. URL http:/www.R-project.org/

Ratter JA, Bridgewater S, Ribeiro JF (2003) Analysis of the floristic composition of the Brazilian Cerrado vegetation. III: Comparison of the woody vegetation of 376 areas. Edinb J Bot 60:57-109

Ratter JA, Richards PW, Argent G, Gifford DR (1973) Observations on the vegetation of the northeastern Mato Grosso. I. The woody vegetation types of the Xavantina-Cachimbo Expedition area. Philos T Roy Soc B 266:449-492

Reatto A, Correia JR, Spera ST (2008) Solos do Bioma do Cerrado: aspectos pedológicos. In: Sano SM, Almeida SP, Ribeiro JF (eds.). Cerrado: Ecologia e Flora. Embrapa-CPAC, Planaltina, pp 107-149 
Ribeiro JF, Walter BMT. 2008. As principais fitofisionomias do bioma Cerrado. In: Sano SM, Almeida SP, Ribeiro JF (eds.). Cerrado: Ecologia e Flora. Embrapa-CPAC, Planaltina, pp 151-212

Shepherd GJ (2009) FITOPAC 2.1 (versão preliminar). Departamento de Biologia Vegetal, Universidade Estadual de Campinas

Silva FAM, Assad ED, Evangelista BA (2008) Caracterização Climática do Bioma Cerrado. In: Sano SM, Almeida SP, Ribeiro JF (eds.). Cerrado: Ecologia e Flora. Embrapa-CPAC, Planaltina, pp 67-88

Silva JF, Fariñas MR, Felfili JM, Klink CA (2006) Spatial heterogeneity, land use and conservation in the cerrado region of Brazil. J Biogeogr 33:536-548

Solórzano A, Pinto JRR, Felfili JM, Hay JDV (2012) Perfil florístico e estrutural do componente lenhoso em seis áreas de cerradão ao longo do bioma Cerrado. Acta Bot Bras 26:328-341

Tóthmérész B (1995) Comparison of different methods for diversity ordering. J Veg Sci 6:283-290

Walther BA, Moore J (2005) The concepts of bias, precision and accuracy, and their use in testing the performance of species richness estimators, with a literature review of estimator performance. Ecography 28:815-829

Zar JH (2010) Biostatistical Analysis. 5th ed., New Jersey, Pearson, Upper Saddle River

Figure 1. Location of the study area ( $\mathbf{0}$ ) in the municipality of Ribeirão Cascalheira, Mato Grosso (Brazil), where we sampled three different types of woody Cerrado vegetation in the Cerrado-Amazon transition zone.

Figure 2. Rarefaction curve $\left(S_{o b s}-M a o\right.$ Tau $)$ based on the number of individuals recorded in the woody Cerrado vegetation of the Cerrado-Amazon transition zone in Ribeirão Cascalheira, Mato Grosso (Brazil). $\mathrm{CO}=$ Cerradão; $\mathrm{DC}=$ Dense Cerrado and TC $=$ Typical Cerrado. The $95 \%$ confidence interval is shaded in gray.

Figure 3. Diversity profiles prepared using the Rényi series, comparing three types of woody Cerrado vegetation in the Cerrado-Amazon transition zone in Ribeirão Cascalheira, Mato Grosso (Brazil). CO = Cerradão (continuous line); $\mathrm{DC}=$ Dense Cerrado $($ dotted line $) ; \mathrm{TC}=$ Typical Cerrado $($ dashed line $)$ and $\left(\mathrm{H}^{\prime}\right.$ $=1$ alpha corresponds to Shannon's index and D = 2 alpha 2 to Simpson's index).

Figure 4. Venn diagram for the distribution of the woody Cerrado plant species found in the CerradoAmazon transition zone in Ribeirão Cascalheira, Mato Grosso (Brazil). CO = Cerradão; DC $=$ Dense 
Cerrado; $\mathrm{TC}=$ Typical Cerrado; $\mathrm{N}=$ number of species; $\mathrm{Cm}_{\mathrm{H}}=$ Morisita's similairty index, and $\mathrm{Ss}=$ Sørensen's index.

Figure 5. The TWINSPAN classification of the 75 subplots sampled in three types of woody cerrado vegetation in the Cerrado-Amazon transition zone in Ribeirão Cascalheira, Mato Grosso (Brazil). CO = Cerradão; $\mathrm{DC}=$ Dense Cerrado, and $\mathrm{TC}=$ Typical Cerrado. Other divisions are not shown here due to their low eigenvalues $(<3)$. 


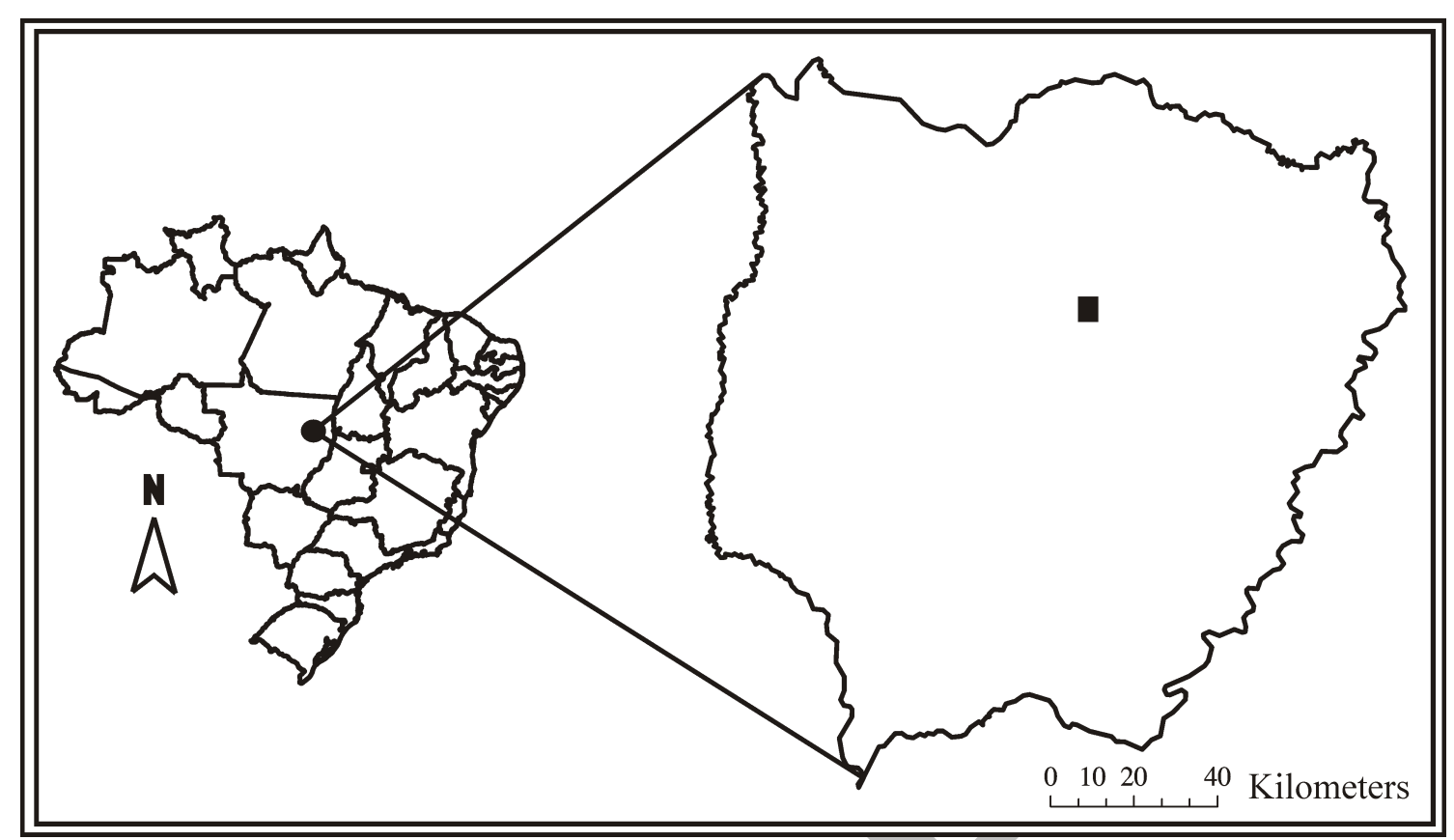

Figure 1 


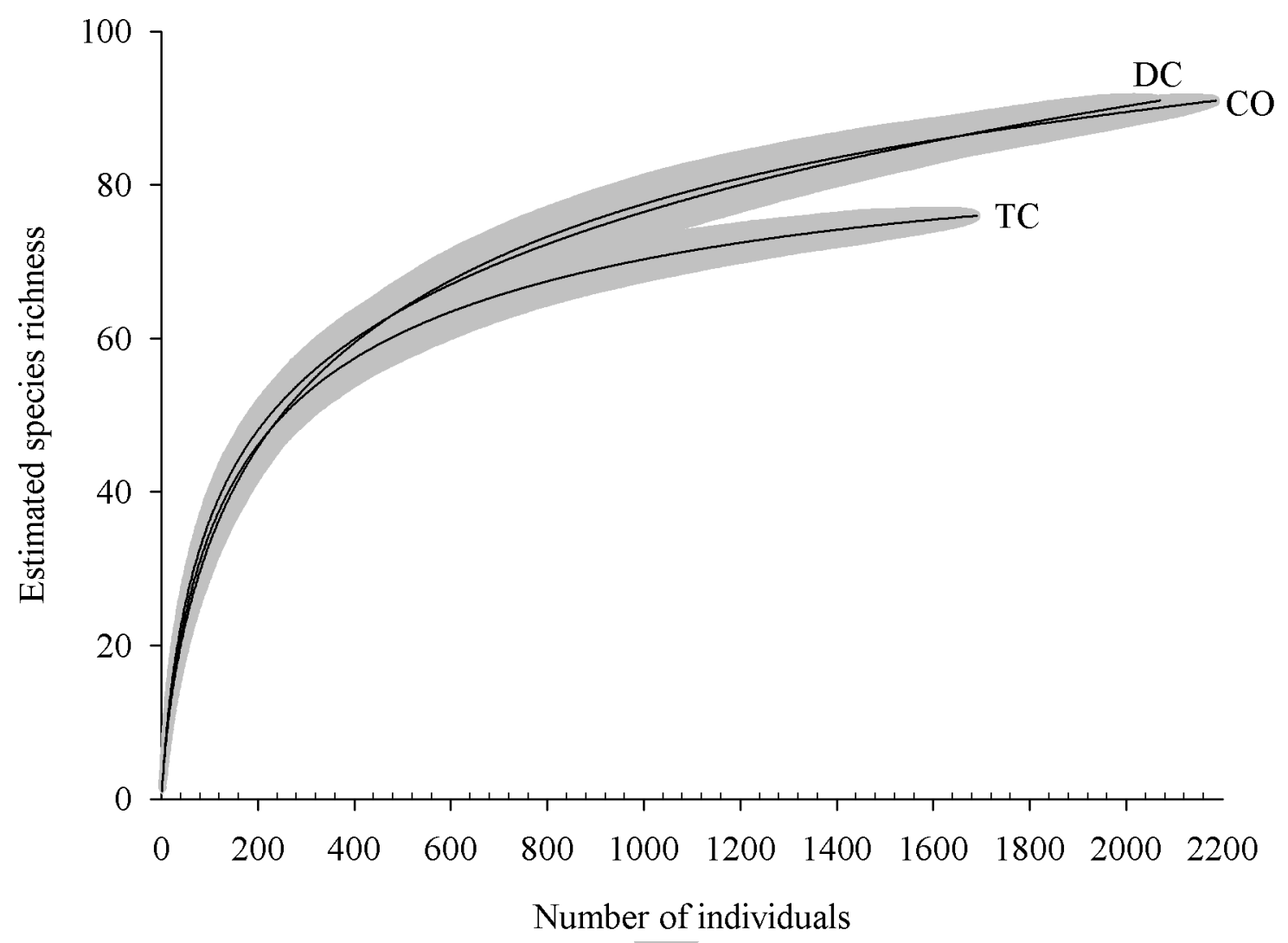

Figure 2 


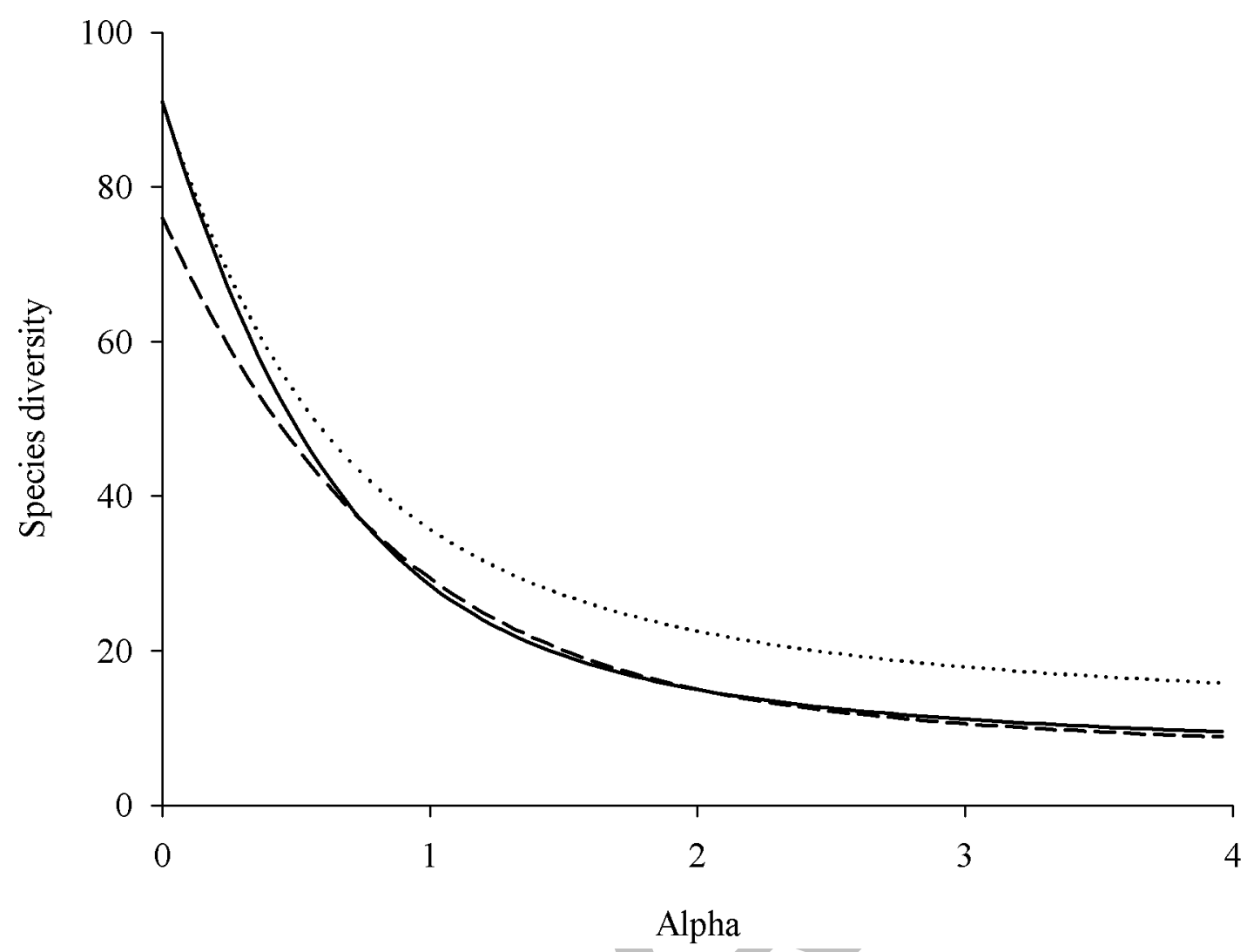

Figure 3 


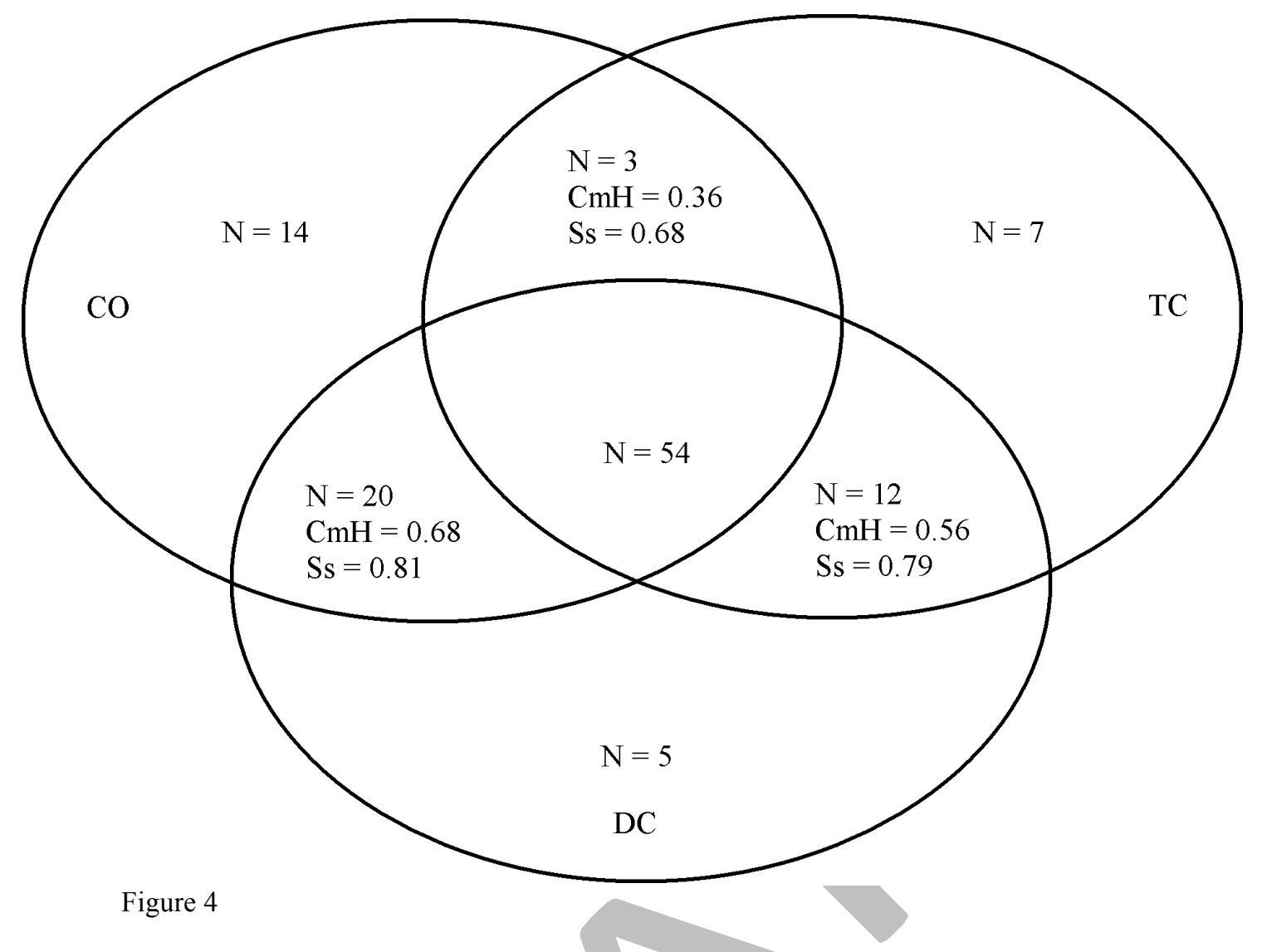




$$
\text { 然 }
$$


Table 1. Density and importance of the woody plant species $\left(\mathrm{D}_{30} \geq 5 \mathrm{~cm}\right)$ found at three sites in the Cerrado-Amazon transition zone in Ribeirão Cascalheira, Mato Grosso (Brazil). $\mathrm{CO}=$ Cerradão; DC $=$ Dense Cerrado; TC $=$ Typical Cerrado. The species with the highest densities and IVI values at each site are shown in bold type. $*=$ indicator species of the Cerradão $(\mathrm{n}=24 ; 20.9 \%) ; * *=$ indicator species of the Dense Cerrado $(\mathrm{n}=16 ; 13.9 \%)$, and $* * *=$ indicator species of the Typical Cerrado $(\mathrm{n}=20 ; 17.4 \%)$. The species are listed in decreasing order of the IVI values recorded at the Cerradão site.

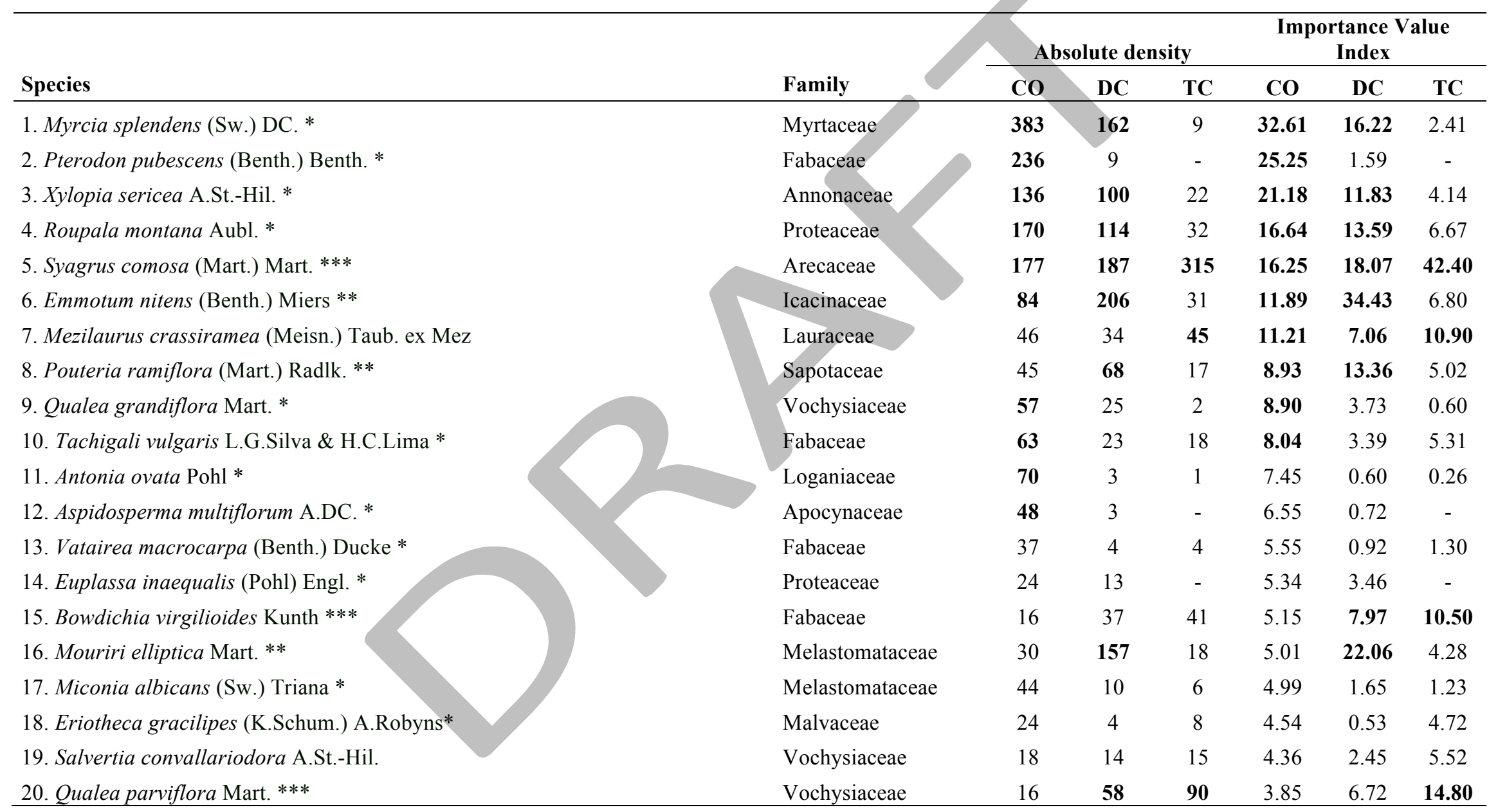




\begin{tabular}{|c|c|c|c|c|c|c|c|}
\hline \multirow[b]{2}{*}{ Species } & \multirow[b]{2}{*}{ Family } & \multicolumn{3}{|c|}{ Absolute density } & \multicolumn{3}{|c|}{$\begin{array}{c}\text { Importance Value } \\
\text { Index }\end{array}$} \\
\hline & & $\mathrm{CO}$ & DC & TC & $\mathrm{CO}$ & DC & TC \\
\hline 21. Aspidosperma tomentosum Mart. ** & Apocynaceae & 25 & 35 & 4 & 3.71 & 6.21 & 1.01 \\
\hline 22. Davilla elliptica A.St.-Hil. *** & Dilleniaceae & 25 & 32 & 213 & 3.61 & 4.08 & 22.70 \\
\hline 23. Qualea multiflora Mart. * & Vochysiaceae & 26 & 14 & - & 3.58 & 2.91 & - \\
\hline 24. Eugenia dysenterica DC. & Myrtaceae & 23 & 28 & 42 & 3.51 & 4.39 & 9.08 \\
\hline 26. Heisteria ovata Benth. * & Olacaceae & 19 & 7 & 1 & 3.13 & 1.40 & 0.25 \\
\hline 27. Schoepfia brasiliensis A.DC. * & Schoepfiaceae & 26 & 2 & - & 3.04 & 0.54 & - \\
\hline 28. Hymenaea stigonocarpa Mart. ex Hayne ** & Fabaceae & 12 & 43 & 8 & 2.95 & 6.19 & 1.84 \\
\hline 29. Xylopia aromatica (Lam.) Mart. & Annonaceae & 18 & 50 & 35 & 2.93 & 5.70 & 6.14 \\
\hline 30. Diospyros hispida A.DC. & Ebenaceae & 15 & 28 & 12 & 2.87 & 3.62 & 2.17 \\
\hline 31. Curatella americana L. *** & Dilleniaceae & 9 & 14 & 48 & 2.59 & 3.68 & 8.47 \\
\hline 33. Handroanthus ochraceus (Cham.) Mattos ** & Bignoniaceae & 9 & 26 & 10 & 2.30 & 5.22 & 2.44 \\
\hline 34. Peltogyne confertiflora (Mart. ex Hayne) Benth. ** & Fabaceae & 10 & 14 & - & 2.28 & 2.63 & - \\
\hline 35. Ouratea hexasperma (A.St.-Hil.) Baill. ** & Ochnaceae & 12 & 32 & 4 & 2.15 & 4.09 & 0.91 \\
\hline 36. Guapira graciliflora (Mart. ex Schmidt) Lundell * & Nyctaginaceae & 9 & - & - & 2.12 & - & - \\
\hline 37. Hirtella glandulosa Spreng. & Chrysobalanaceae & 9 & 6 & 3 & 2.09 & 1.39 & 0.70 \\
\hline 38. Licania humilis Cham. \& Schltdl. ** & Chrysobalanaceae & 10 & 24 & 6 & 2.01 & 4.51 & 1.73 \\
\hline 39. Rourea induta Planch. ** & Connaraceae & 11 & 34 & 18 & 1.93 & 4.66 & 3.23 \\
\hline 40. Byrsonima coccolobifolia Kunth ** & Malpighiaceae & 9 & 37 & 56 & 1.86 & 4.97 & 8.49 \\
\hline 41. Vochysia rufa Mart. & Vochysiaceae & 9 & 8 & 10 & 1.72 & 1.26 & 2.34 \\
\hline 42. Aspidosperma macrocarpon Mart. * & Apocynaceae & 8 & 2 & 1 & 1.62 & 0.51 & 0.39 \\
\hline 43. Dalbergia miscolobium Benth. & Fabaceae & 5 & 2 & - & 1.28 & 0.57 & - \\
\hline 44. Miconia stenostachya DC. * & Melastomataceae & 7 & - & 1 & 1.27 & - & 0.28 \\
\hline
\end{tabular}




\begin{tabular}{|c|c|c|c|c|c|c|c|}
\hline \multirow[b]{2}{*}{ Species } & \multirow[b]{2}{*}{ Family } & \multicolumn{3}{|c|}{ Absolute density } & \multicolumn{3}{|c|}{$\begin{array}{c}\text { Importance Value } \\
\text { Index }\end{array}$} \\
\hline & & $\mathrm{CO}$ & DC & TC & CO & DC & TC \\
\hline 45. Vochysia haenkeana Mart. * & Vochysiaceae & 6 & - & - & 1.14 & - & - \\
\hline 46. Brosimum gaudichaudii Trécul * & Moraceae & 5 & - & - & 1.05 & - & - \\
\hline 47. Byrsonima pachyphylla A.Juss. *** & Malpighiaceae & 5 & 42 & 36 & 1.02 & 5.3 & 5.93 \\
\hline 48. Tabebuia aurea (Silva Manso) Benth. \& Hook.f. ex S.Moore & Bignoniaceae & 4 & 10 & 9 & 1.02 & 2.75 & 1.98 \\
\hline 50. Connarus suberosus Planch. *** & Connaraceae & 5 & 3 & 57 & 1.01 & 0.59 & 8.24 \\
\hline 51. Guapira noxia (Netto) Lundell * & Nyctaginaceae & 4 & - & - & 0.96 & - & - \\
\hline 52. Leptolobium dasycarpum Vogel & Fabaceae & 4 & 1 & - & 0.90 & 0.20 & - \\
\hline 53. Chaetocarpus echinocarpus (Baill.) Ducke & Peraceae & 4 & 4 & - & 0.89 & 0.55 & - \\
\hline 54. Aspidosperma nobile Müll.Arg. & Apocynaceae & 4 & 2 & - & 0.88 & 0.28 & - \\
\hline 55. Annona coriacea Mart. * & Annonaceae & 5 & - & - & 0.88 & - & - \\
\hline 57. Virola sebifera Aubl. ** & Myristicaceae & 4 & 16 & - & 0.83 & 2.10 & - \\
\hline 58. Hancornia speciosa Gomes & Apocynaceae & 4 & 3 & - & 0.82 & 0.61 & - \\
\hline 59. Myrcia sp. & Myrtaceae & 4 & 11 & 11 & 0.81 & 1.85 & 2.43 \\
\hline 60. Simarouba versicolor A.St.-Hil. & Simaroubaceae & 3 & 1 & - & 0.72 & 0.33 & - \\
\hline 61. Himatanthus sucuuba (Spruce ex Müll.Arg.) Woodson & Apocynaceae & 3 & 1 & - & 0.72 & 0.20 & - \\
\hline 62. Cybianthus detergens Mart. & Primulaceae & 3 & 3 & 1 & 0.65 & 0.59 & 0.36 \\
\hline 63. Maprounea guianensis Aubl. & Euphorbiaceae & 3 & 3 & 1 & 0.65 & 0.60 & 0.29 \\
\hline 64. Salacia crassifolia (Mart. ex Schult.) G.Don *** & Celastraceae & 3 & 10 & 34 & 0.63 & 1.75 & 6.59 \\
\hline 65. Myrcia bella Cambess. & Myrtaceae & 3 & 1 & 4 & 0.62 & 0.21 & 0.89 \\
\hline 66. Myrcia rimosa Cambess. *** & Myrtaceae & 3 & 42 & 85 & 0.60 & 4.75 & 10.30 \\
\hline 67. Heteropterys byrsonimifolia A.Juss. & Malpighiaceae & 3 & - & 3 & 0.60 & - & 0.74 \\
\hline 68. Syagrus flexuosa (Mart.) Becc. ** & Arecaceae & 3 & 11 & 1 & 0.48 & 1.95 & 0.23 \\
\hline
\end{tabular}




\begin{tabular}{|c|c|c|c|c|c|c|c|}
\hline \multirow[b]{2}{*}{ Species } & \multirow[b]{2}{*}{ Family } & \multicolumn{3}{|c|}{ Absolute density } & \multicolumn{3}{|c|}{$\begin{array}{c}\text { Importance Value } \\
\text { Index }\end{array}$} \\
\hline & & $\mathrm{CO}$ & DC & TC & $\mathrm{CO}$ & DC & TC \\
\hline 69. Dimorphandra mollis Benth. & Fabaceae & J & 1 & 8 & 0.48 & 0.23 & 2.12 \\
\hline 70. Couepia grandiflora (Mart. \& Zucc.) Benth. & Chrysobalanaceae & 2 & - & - & 0.44 & - & - \\
\hline 71. Lafoensia pacari A.St.-Hil. ** & Lythraceae & 2 & 40 & 2 & 0.43 & 5.35 & 0.37 \\
\hline 72. Eugenia gemmiflora O.Berg *** & Myrtaceae & 2 & 5 & 39 & 0.41 & 1.01 & 7.87 \\
\hline 74. Ferdinandusa elliptica (Pohl) Pohl & Rubiaceae & 2 & 1 & - & 0.34 & 0.21 & - \\
\hline 75. Miconia sp. 2 & Melastomataceae & 1 & - & - & 0.30 & - & - \\
\hline 76. Byrsonima verbascifolia (L.) DC. *** & Malpighiaceae & 1 & 16 & 64 & 0.28 & 3.23 & 10.6 \\
\hline 77. Miconia sp. 1 & Melastomataceae & 1 & 1 & - & 0.27 & 0.20 & - \\
\hline 78. Cybistax antisyphilitica (Mart.) Mart. & Bignoniaceae & 1 & - & - & 0.26 & - & - \\
\hline 79. Enterolobium gummiferum (Mart.) J.F.Macbr. & Fabaceae & 1 & 1 & - & 0.24 & 0.21 & - \\
\hline 81. Annona crassiflora Mart. ** & Annonaceae & 1 & 26 & 22 & 0.21 & 3.87 & 4.36 \\
\hline 82. Eugenia aurata O.Berg *** & Myrtaceae & 1 & 8 & 18 & 0.21 & 1.22 & 3.59 \\
\hline 83. Alchornea discolor Poepp. & Euphorbiaceae & 1 & 1 & - & 0.21 & 0.21 & - \\
\hline 84. Tocoyena formosa (Cham. \& Schltdl.) K.Schum. & Rubiaceae & 1 & 1 & 3 & 0.21 & 0.20 & 0.69 \\
\hline 85. Copaifera cf. martii Hayne & Fabaceae & 1 & - & - & 0.21 & - & - \\
\hline 86. Fridericia cinnamomea (DC.) L.G.Lohmann & Bignoniaceae & 1 & - & - & 0.21 & - & - \\
\hline 87. Protium heptaphyllum (Aubl.) Marchand & Burseraceae & 1 & 1 & - & 0.21 & 0.20 & - \\
\hline 88. Myrcia multiflora (Lam.) DC. ** & Myrtaceae & 1 & 76 & 19 & 0.20 & 8.05 & 3.50 \\
\hline 89. Pseudobombax longiflorum (Mart. \& Zucc.) A.Robyns & Malvaceae & 1 & 3 & - & 0.20 & 0.53 & - \\
\hline 90. Byrsonima intermedia A.Juss. & Malpighiaceae & 1 & 2 & 2 & 0.20 & 0.42 & 0.55 \\
\hline 91. Erythroxylum sp. & Erythroxylaceae & 1 & - & - & 0.20 & - & - \\
\hline 92. Strychnos pseudoquina A.St.-Hil. & Loganiaceae & - & 5 & 7 & - & 1.19 & 3.39 \\
\hline
\end{tabular}




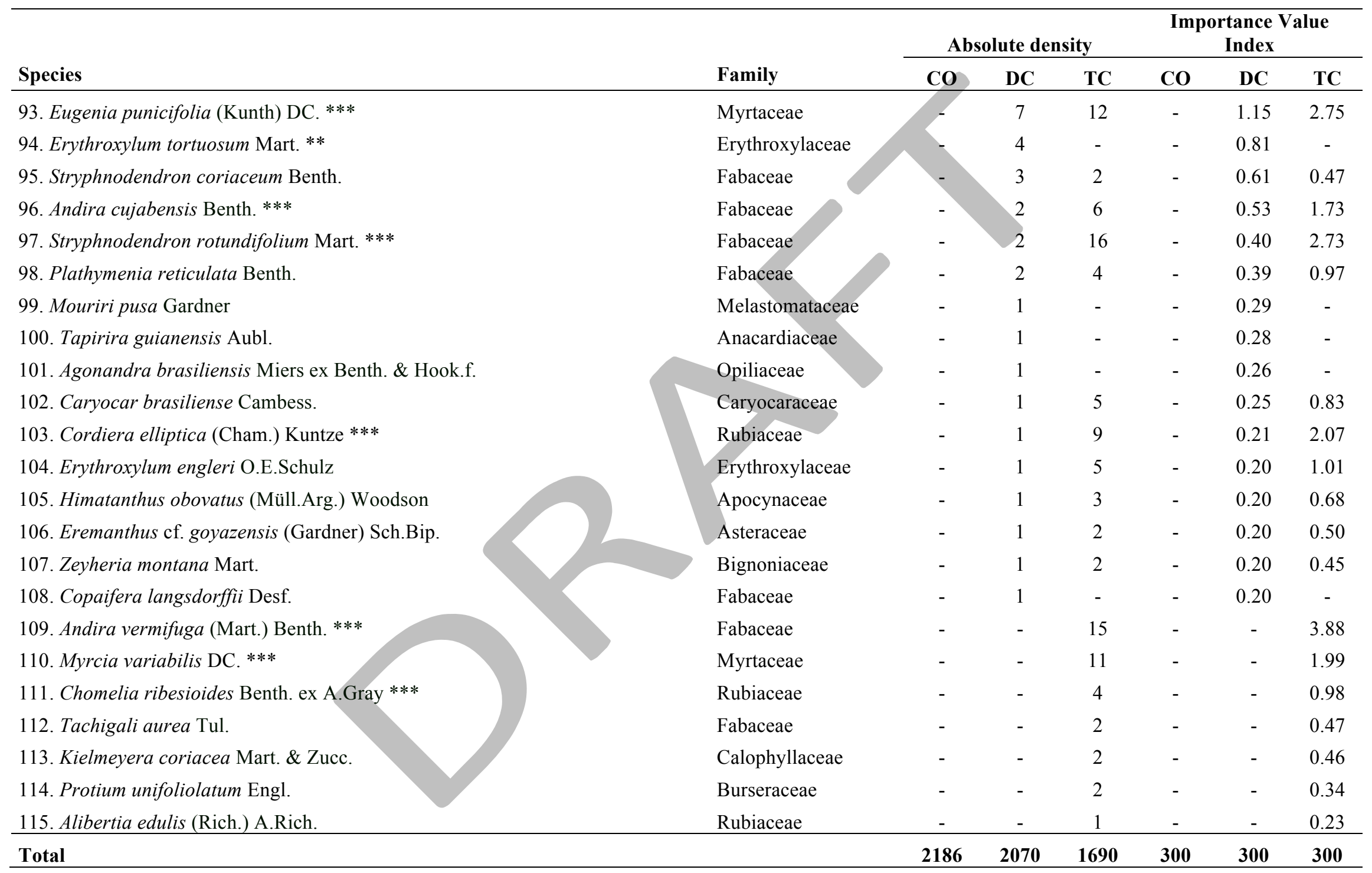




$$
0^{2 x^{4}}
$$

